\title{
FROM ARRANGEMENTS TO NEW COMPOSITIONS SEVENTEENTH-CENTURY FRENCH DANCE MUSIC IN PORTUGUESE AND SPANISH KEYBOARD SOURCES TO 1720
}

\author{
ANDREW WOOLLEY \\ Centro de Estudos de Sociologia e Estética Musical, Faculdade de Ciências Sociais \\ e Humanas, Universidade Nova de Lisboa
}

Izvleček: Razprava na podlagi štirih rokopisnih virov za glasbila s tipkam razlaga, kako so se $v$ poznem 17. in $v$ 18. stoletju širili in prirejali viri za plesno glasbo francoskega tipa na Portugalskem in v Španiji. Avtor poudari pomen zapisa $v$ obliki izvlečka za glasbila s tipkami, ki je poenostavil prenos obravnavanega repertoarja, ter razpravlja o prilagajanju tega tipa zapisa lokalnemu okusu in takratnim praksam. Ključne besede: Jean-Baptiste Lully, Pedro de Araújo, Martin y Coll, Portugalska, Španija
Abstract: Focussing on four keyboard manuscripts, this article discusses the dissemination, arrangement and adaptation of French-style dance music in Portugal and Spain in the late seventeenth and early eighteenth centuries. It highlights the importance of short scores in facilitating its transmission and discusses how adaptations accorded with local tastes and practices.

Keywords: Jean-Baptiste Lully, Pedro de Araújo, Martin y Coll, Portugal, Spain

Much French dance music of the seventeenth century survives in sources originating from outside of France. A well-known example is Michael Praetorius's Terpsichore (Wolfenbüttel, 1612), a collection of French and French-inspired courtly dances in consort arrangements. ${ }^{1}$ It is significant not only for the many unique dances in fine versions but also for its prefatory texts implying how this music was typically disseminated: the melodies, and some of the bass parts as well, had been obtained by Praetorius from Antoine Emeraud, the French dancing master attached to the court of the collection's dedicatee Friedrich Ulrich, Duke of Braunschweig and Lüneburg. Praetorius's role was therefore that of a specialist musician commissioned to make arrangements destined for court dance ensembles, who drew on sources primarily notated as a single line only. This was a form of notation common among dancing masters in the late sixteenth and seventeenth centuries which is found in several sources associated with dancing masters, including Thoineau Arbeau's treatise Orchésographie (1589), containing descriptions of dance choreographies with the associated music notated as a simple melody, and John Playford's series The Dancing Master, a collection of dance melodies with choreographic descriptions initiated in $1651 .{ }^{2}$

1 Holman, "Terpsichore at 400", 41-42.

2 Arbeau, Orchesographie; Playford, Complete Country Dance Tunes. 
For dancing masters, the purpose of notation would have been to facilitate the making of arrangements for dance ensembles, especially since many of them are likely to have memorised dance tunes for use in day-to-day situations. ${ }^{3}$ Yet the styles and idioms of this music had a wider appeal, reflected especially in the many arrangements that appear in sources for keyboard, guitar, lute, harp and related instruments. The sources of these arrangements originate from many countries - examples survive from England, France, Germany, the Netherlands, Portugal, Spain and elsewhere - and demonstrate the existence of French dance music in places where a culture of French-style dancing existed for which no sources of consort arrangements (intended for actual dancing) survive. ${ }^{4}$ Many would have served the recreational or teaching needs of wealthy amateurs in domestic contexts, but others are associated with professional musicians and offer insights into the various ways in which this music was adapted for local needs beyond the ballroom; several examples of the latter for keyboard from Portugal and Spain are the focus of this article.

Drawing in part on information previously published by Bruce Gustafson and Maurice Esses, Table 1 lists concordances for the three most important Spanish and Portuguese keyboard sources of French-style dance music. ${ }^{5}$ One important feature to note is that there are a large number of dances in French style that do not survive elsewhere. A possible explanation is that some were composed by local musicians, as suggested by other sources: for example, no concordances have been identified for the five pieces called "Zarabanda francesa" in Gaspar Sanz's Instrucción de música sobre la guitarra española (Saragossa, 1674), a fact that has been taken to mean that Sanz was their composer. ${ }^{6}$ Imported music does, nevertheless, form a significant part of the corpus and is found especially in sources from the first two decades of the eighteenth century. The most significant examples from Spain for keyboard are two manuscript anthologies compiled by the organist and Franciscan friar, composer and theorist Martin y Coll in c. 1706 and c. 1709 (E-Mn, M1357 and M1360), which contain miscellaneous airs and dances and a large quantity of tiento-like pieces (fantasy-like pieces) and versets. ${ }^{7}$ Many dances of French origin are likewise found in a published guitar collection of 1714, Resumen de acompañar la parte con la guitarra by Santiago de Murcia (1673-1739). ${ }^{8}$

Two Portuguese sources from the same pre-1720 period whose French-style dances have been overlooked are P-BRad, MS 964, a guardbook of keyboard music in contrapuntal genres, Latin sacred vocal music and miscellaneous airs, and P-Lcg, MS without shelfmark, a collection for five-course guitar also containing airs written in a cipher notation for

3 Ward, "Newly Devis'd Measures for Jacobean Masques"; Holman, Four and Twenty Fiddlers, 193-194.

4 For aristocratic dancing in seventeenth-century Spain, see Esses, Dance and Instrumental Diferencias, vol. 1, 517-526; and Brooks, Art of Dancing. For sources of keyboard arrangements, see Woolley, "Catalogue of the "French Dances"”.

5 Gustafson, French Harpsichord Music, vol. 1, 87-89, and vol. 2, 260-266; Esses, Dance and Instrumental Diferencias, vol. 1, 251-256, 259-265. The table defines "French style" loosely and includes any binary-form movement with a recognisable French-dance prototype.

6 Esses, Dance and Instrumental Diferencias, vol. 2, D448-D452.

7 For Martin y Coll, see Esses, Dance and Instrumental Diferencias, vol. 1, 254-255.

8 Russell, "Santiago de Murcia"; Vera, "Santiago de Murcia's Cifras selectas de guitarra". 
several instruments including harpsichord. ${ }^{9}$ The word "Francezas" appears over one of the pieces in P-BRad, MS 964, but its French contents have not been recognised, partly on account of several inscriptions implying that the airs in this manuscript are of Italian origin (Figure 1). Although it is written in the hand of the principal copyist of the source, it is possible that this inscription was added some time after copying, perhaps when the manuscript was bound, since it has been crammed into vacant space at the top of a page.

Figure 1

The beginning of the group of Frenchstyle dances in P-BRad, MS 964, headed "ytalianaz pa . orgão". (Reproduced by permission of the Universidade do Minho, Arquivo Distrital de Braga.)

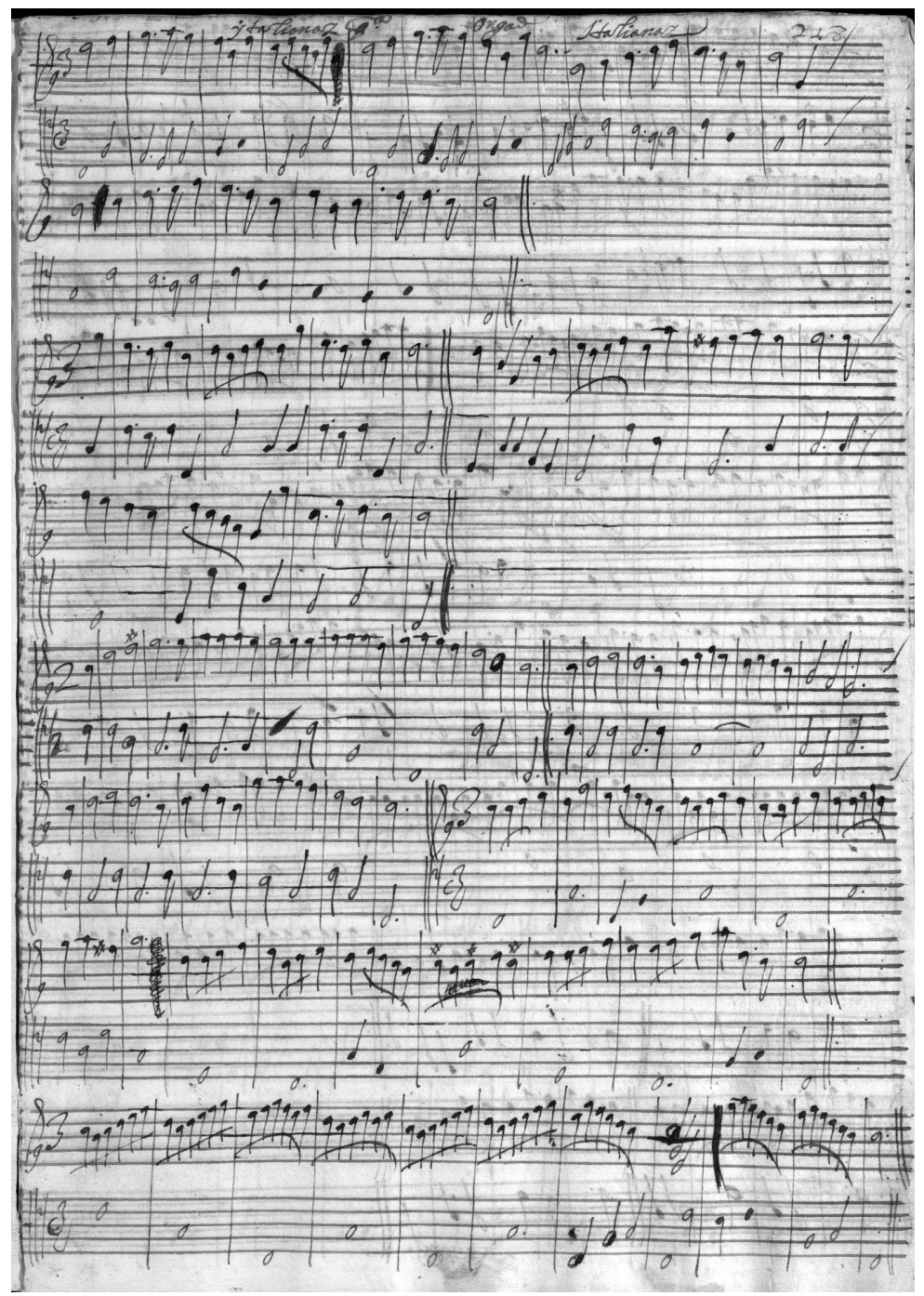

9 Doderer, Obras selectas para órgão; Doderer, Orgelmusik und Orgelbau; Esses, Dance and Instrumental Diferencias, vol. 1, 271-272; Budasz, "Five-Course Guitar", 89-92, 98. 
Table 1

French-style dances in E-Mn, M1357; E-Mn, M1360; and P-BRad, MS 964

\begin{tabular}{|c|c|c|}
\hline \multicolumn{3}{|r|}{ Sarabande } \\
\hline [1.] & "Corriente; Corneta" [d] & E-Mn, M1357, 18-19 \\
\hline [2.] & $\begin{array}{l}\text { "otra cancion" ("seade tocar } \\
\text { graue") }[\mathrm{D}] \text { and "otra cancion } \\
\text { para ecos" }[\mathrm{C}]\end{array}$ & E-Mn, M1357, 50-51, 173-174 \\
\hline [3.] & "Cancion de clarin" [D] & E-Mn, M1357, 51 \\
\hline [4.] & $\begin{array}{l}\text { "Zarabanda francesa, } \\
\text { despacio," }[\mathrm{C}]\end{array}$ & E-Mn, M1357, 88-92 \\
\hline [5.] & "Zarabandas." [d] & E-Mn, M1360, fols. 205V-206 \\
\hline [6.] & "Segunda." [a] & E-Mn, M1360, fol. 206 \\
\hline [7.] & "Terzera." [a] & E-Mn, M1360, fols. 206-207 \\
\hline [8.] & "Quarta." $[\mathrm{C}]$ & $\begin{array}{l}\text { E-Mn, M1360, fol. 207; adopts a repeating four-bar harmonic pattern also } \\
\text { found in Woolley }{ }^{\dagger} \text { n. } 23 \text {. }\end{array}$ \\
\hline [9.] & "Quinta" [C] & E-Mn, M136o, fols. 207-207v \\
\hline [10.] & "Sexta." [C] & E-Mn, M1360, fol. 207v \\
\hline [11.] & "Septima" [C] & $\begin{array}{l}\text { E-Mn, M136o, fols. } 208-208 \mathrm{v} \text {; adopts a repeating four-bar harmonic pattern } \\
\text { also found in Woolley }{ }^{\dagger} \text { no. } 23 \text {. }\end{array}$ \\
\hline [12.] & "Ruede La bola." [C] & E-Mn, M136o, fols. 221-221v \\
\hline [13.] & "25." [D] & E-Mn, M1360, fols. 242-242V \\
\hline [14.] & "estrangeiras, ou italianas" [d] & P-BRAd, MS 964, fol. 216 \\
\hline [15.] & $\begin{array}{l}\text { "Sarabande", "Italianaz ou } \\
\text { estrangeiraz pa. orgão. ou } \\
\text { Arpa." [C] }\end{array}$ & P-BRad, MS 964, fol. 217 \\
\hline [16.] & [Sarabande] [g] & P-BRAd, MS 964, fol. $220=$ LWV $57 / 47$ \\
\hline [17.] & $\begin{array}{l}\text { "Estrangeira", "ia. Dansa" ("2a.", } \\
\text { "3a.", "4.".) [a] }\end{array}$ & P-BRAd, MS 964, fol. 222v \\
\hline \multicolumn{3}{|r|}{ Menuet } \\
\hline [18.] & "Cancion françessa" [d] & E-Mn, M1357, 22-24 \\
\hline [19.] & $\begin{array}{l}\text { "Cancion de clarin, con eco a } \\
\text { discrecion" [D] }\end{array}$ & E-Mn, M1357, 49-50 = LWV 63/24 \\
\hline [20.] & "Minue frances" [d] & E-Mn, M1357, 51-52 = LWV 60/73 \\
\hline [21.] & "Minué Franzesa" [g] & E-Mn, M1357, 231-232 \\
\hline [22.] & "Otro Minué" [G] & E-Mn, M1357, 232 \\
\hline [23.] & "Minue 10." [g] & E-Mn, M1357, 273-274 = LWV 60/5 \\
\hline [24.] & "Minue 2." [g] & E-Mn, M1357, 274-275 = LWV 54/11 \\
\hline [25.] & "Minue 3." [C] & E-Mn, M1357, 275-276 = LWV 61/3 \\
\hline [26.] & "Minue 4." $[\mathrm{C}]$ & E-Mn, M1357, 276 = LWV $65 / 63$ \\
\hline [27.] & "Minue 5." [C] & E-Mn, M1357, 276-277 = LWV 57/19 \\
\hline [28.] & "Minue 6." [d] & E-Mn, M1357, 277-278 \\
\hline [29.] & "Minuetes" [a] & E-Mn, M136o, fol. 208v \\
\hline [30.] & "Otro" [C] & E-Mn, M136o, fols. $208 v-209$ \\
\hline [31.] & "Otro" $[\mathrm{C}]$ & E-Mn, M136o, fol. 209 \\
\hline [32.] & "Otro" $[\mathrm{C}]$ & E-Mn, M1360, fol. 209v \\
\hline
\end{tabular}




\begin{tabular}{|c|c|c|}
\hline [33.] & "Otro" $[\mathrm{C}]$ & $\begin{array}{l}\text { E-Mn, M1360, fol. 209v; E-Mn, M815, fol. 17v ("Minuet de la Marcha”); } \\
\text { Gautier, “Trio", } 112 \text { ("Menuet Rondeau”). See Gustafson 2018," } 24 .\end{array}$ \\
\hline [34.] & "Otro" $[\mathrm{C}]$ & E-Mn, M136o, fol. 210 \\
\hline [35.] & "Otro" $[\mathrm{C}]$ & E-Mn, M136o, fols. $210-210 \mathrm{~V}=\mathrm{LWV} 71 / 13$ \\
\hline [36.] & “Otro" $[\mathrm{C}]$ & E-Mn, M1360, fols. 210V-211 = LWV 50/14 \\
\hline [37.] & "Otro" $[\mathrm{C}]$ & E-Mn, M1360, fol. $211=$ LWV 50/15 \\
\hline [38.] & "10." [D] & E-Mn, M136o, fol. 232V \\
\hline [39.] & “2." [d] & E-Mn, M136o, fol. 233 \\
\hline [40.] & “5." [B flat $]$ & E-Mn, M1360, fol. 234 \\
\hline [41.] & “60." [B flat] & E-Mn, M1360, fol. 234V \\
\hline [42.] & “9." $[\mathrm{F}]$ & E-Mn, M1360, fol. $236=$ LWV $65 / 4$ \\
\hline [43.] & “10." $[\mathrm{F}]$ & E-Mn, M1360, fols. $236-236 \mathrm{v}=\mathrm{LWV} 65 / 5$ \\
\hline [44.] & “11." $[\mathrm{C}]$ & E-Mn, M1360, fol. 236v \\
\hline [45.] & "12." [D] & E-Mn, M136o, fol. 237 \\
\hline [46.] & “13." [D] & E-Mn, M1360, fol. 237v \\
\hline [47.] & “16." $[\mathrm{g}]$ & E-Mn, M1360, fol. 238v \\
\hline [48.] & "17."; [no title] [C] & E-Mn, M1360, fol. 239; P-BRad, MS 964, fol. $221=$ LWV 61/2 \\
\hline [49.] & $\begin{array}{l}\text { "19." [D]; "italianaz pa. orgão" } \\
{[C]}\end{array}$ & $\begin{array}{l}\text { E-Mn, M1360, fol. 240; P-BRad, MS 964, fol. } 218 \text { and fol. 219v (bass lacking) } \\
=\text { LWV 60/72 }\end{array}$ \\
\hline [50.] & “20." [D] & E-Mn, M136o, fol. $240 \mathrm{~V}$ \\
\hline [51.] & “21." [D] & E-Mn, M1360, fol. $240 \mathrm{~V}$ \\
\hline [52.] & “27." [a] & E-Mn, M1360, fol. 243 \\
\hline [53.] & "Minuete. Ayroz" [G] & P-BRad, MS 964, fol. 216v \\
\hline [54.] & "Menuet" [C] & P-BRad, MS 964, fol. 217 \\
\hline [55.] & "[II] Menuet" [C] & P-BRad, MS 964, fol. 217 \\
\hline [56.] & $\begin{array}{l}\text { "Augusto Principe", "Italianas } \\
\text { ou estrangeiras" [g] }\end{array}$ & P-BRad, MS 964, fol. $216 \mathrm{~V}^{\dagger \dagger}$ \\
\hline [57.] & "Minuet" [C] & P-BRad, MS 964, fol. $217 \mathrm{~V}$ \\
\hline [58.] & {$[$ Minuet and double] $[\mathrm{C}]$} & P-BRad, MS 964, fol. 218 and fols. $220 \mathrm{~V}-221^{\ddagger \neq}$ \\
\hline [59.] & [Minuet] [C] & P-BRad, MS 964, fol. 218v = LWV 51/7 \\
\hline [60.] & [Minuet] $[\mathrm{C}]$ & P-BRad, MS 964, fol. 218v = LWV 35/4 \\
\hline [61.] & [Trompettes: Minuet] [C] & P-BRad, MS 964, fol. 218v = LWV 51/5 \\
\hline [62.] & [Minuet] [d] & P-BRad, MS 964, fol. 219 \\
\hline [63.] & "Francezas" [B flat-g] & $\begin{array}{l}\text { P-BRad, MS 964, fol. } 220=\text { LWV 59/27 joined with Purcell: "If Love's a Sweet } \\
\text { Passion". }\end{array}$ \\
\hline [64.] & [Minuet] [c] & $\begin{array}{l}\text { P-BRad, MS 964, fol. 220v = Gautier, Symphonies (1707), 2-3 ("Les heures } \\
\text { heureuses") }\end{array}$ \\
\hline [65.] & [Minuet] $[\mathrm{d}-\mathrm{G}]$ & P-BRad, MS 964, fol. 221 \\
\hline [66.] & [Minuet $][\mathrm{C}]$ & P-BRad, MS 964, fol. 221 \\
\hline [67.] & [Minuet] [d] & P-BRad, MS 964, fol. $221 \mathrm{~V}$ \\
\hline [68.] & "Minuetta" $[\mathrm{C}]$ & P-BRad, MS 964, fol. 230 \\
\hline [69.] & "Minuete della Posta" [D] & P-BRad, MS 964, fols. $257-257 \mathrm{~V}$ \\
\hline [70.] & "Minuete" [d] & P-BRad, MS 964, fol. 258v \\
\hline [71.] & "Minuete" [D] & P-BRad, MS 964, fol. 258v \\
\hline
\end{tabular}




\begin{tabular}{|c|c|c|}
\hline \multicolumn{3}{|r|}{ Canary / Passepied / Gigue } \\
\hline [72.] & $\begin{array}{l}\text { "Prado de Sr. Geronimo. } \\
\text { [Canary]" [C] }\end{array}$ & $\begin{array}{l}\text { E-Mn, M1360, fol. 221; E-Mn, M1359, 605-606 (“Al Prado de Sr. Geronimo." } \\
\text { [G]) }\end{array}$ \\
\hline [73.] & "Canarios" $[\mathrm{C}]$ & $\begin{array}{l}\text { E-Mn, M1360, fols. 221V-222V = a combination of LWV 69/26, LWV 69/27 } \\
\text { and LWV 71/54. }\end{array}$ \\
\hline [74.] & "Otro genero de canarios" $[\mathrm{C}]$ & E-Mn, M1360, fol. 222v. The harmonic structure follows Woolley ${ }^{\dagger}$ no. 54. \\
\hline [75.] & "Gigue" [d] & E-Mn, M1360, fols. 223v-224 \\
\hline [76.] & $\begin{array}{l}\text { "Entrada de Bretons } \\
{[\text { Passepied]" [C] }}\end{array}$ & E-Mn, M1360, fol. 224V = LWV 69/30 \\
\hline [77.] & "Obra de Pensie [Gigue]" [C] & E-Mn, M1360, fol. 225V = LWV 60/71 [D] \\
\hline [78.] & "22. [Gigue]" [c] & E-Mn, M1360, fol. 241 \\
\hline [79.] & "24. [Gigue]" [C] & E-Mn, M1360, fol. 241V-242 \\
\hline \multicolumn{3}{|r|}{ Chaconne / Passacaille } \\
\hline [80.] & "La Chacona" [g] & E-Mn, M1360, fol. 217V-220V = LWV 71/61 \\
\hline [81.] & "Pasacalles" [d] & E-Mn, M1360, fol. 222v-223 \\
\hline [82.] & "Passagagli" [C] & P-BRAd, MS 964, fol. 226v-227 \\
\hline \multicolumn{3}{|r|}{ Marche / Rigaudon / multi-sectional } \\
\hline [83.] & "Matassins" [C] & E-Mn, M1360, fol. 223-223V = LWV 40/18 (= LWV 52/47 and LWV 47/21) \\
\hline [84.] & [Minuet-canary-minuet] [g] & P-BRad, MS 964, fol. 219v \\
\hline [85.] & $\begin{array}{l}\text { "La Marche de Gantier } \\
\text { [Gautier]" [C] }\end{array}$ & $\begin{array}{l}\text { E-Mn, M1360, fol. } 225 \text { (with LWV } 73 / 7 \text { appended); E-Mn, M815, fol. 16v } \\
\text { ("Marcha”); GB-0b, Mus. Sch. MS F.576, fol. 76; see Gustafson 2018," } 24 .\end{array}$ \\
\hline [86.] & " $3^{0 .} .[\mathrm{g}]$ & E-Mn, M1360, fols. 233-233V = LWV 61/37 \\
\hline [87.] & "4." [B flat]; [no title] [C] & E-Mn, M136o, fols. 233v-234; P-BRad, MS 964, fol. 220v \\
\hline [88.] & " $7^{0} . "[\mathrm{~g}]$ & E-Mn, M136o, fols. 234V-235v \\
\hline [89.] & "18." [B flat] & E-Mn, M136o, fols. 239v-240 \\
\hline [90.] & “26."; [no title] [C] & E-Mn, M1360, fols. 242v-243; P-BRad, MS 964, fol. $218=$ LWV 73/6 \\
\hline [91.] & {$[$ Marche] $[\mathrm{C}]$} & P-BRad, MS 964, fol. $219=$ LWV 51/32 \\
\hline [92.] & [Rigaudon] [C] & $\begin{array}{l}\text { P-BRad, MS 964, fols. } 220 \mathrm{a} \text { and 221; Gautier, “Trio", } 89 \text { (“Rigaudon”); Gautier, } \\
\text { Symphonies (1707), } 22 \text { ("II }{ }^{\text {me }} \text { Rigaudon") [D] }\end{array}$ \\
\hline \multicolumn{3}{|r|}{ Gavotte } \\
\hline [93.] & "Ballet." [d] & E-Mn, M136o, fol. 226v \\
\hline [94.] & "Jaboste de Ardel" [a] & E-Mn, M1360, fol. 227. See Gustafson 1979, ${ }^{\$ 5}$ II:265. \\
\hline [95.] & [No title] [d] & P-BRad, MS 964, fol. 218v = LWV 65/12 \\
\hline \multicolumn{3}{|r|}{ Bourée } \\
\hline [96.] & "Otro" [d] & E-Mn, M1360, fol. 211v; see Woolley ${ }^{\dagger}$ no. 26. \\
\hline [97.] & "Monica Forsata" [Bourée] [d] & $\begin{array}{l}\text { E-Mn, M1360, fol. 228; E-Mn, M815, fol. } 12 \mathrm{~V} \text { ("el sarado, o Bella Lis por otro } \\
\text { nombre") = LWV 14/2 (see Table 2). }\end{array}$ \\
\hline [98.] & "80." [C] & E-Mn, M1360, fol. 235V = LWV 61/15 \\
\hline [99.] & “14" [g] & E-Mn, M136o, fols. $237 \mathrm{~V}-238$ \\
\hline [100.] & “15." [F] & E-Mn, M136o, fols. $238-238 \mathrm{v}$ \\
\hline [101.] & “23." [C] & E-Mn, M1360, fol. 241v \\
\hline [102.] & “28.; [ [no title] [C] & E-Mn, M1360, fols. 243-243v; P-BRAd, MS 964, fol. $218=$ LWV 73/7 \\
\hline [103.] & [no title] [d] & P-BRad, MS 964, fol. 220 \\
\hline
\end{tabular}




\begin{tabular}{|c|c|c|}
\hline \multicolumn{3}{|r|}{ Other } \\
\hline$[104$. & $\begin{array}{l}\text { [Air: "Vous ne devez plus } \\
\text { attendre"] [g] }\end{array}$ & P-BRad, MS 964, fols. 219-219v and fol. $221 \mathrm{v}$ (two versions) = LWV 63/36 \\
\hline$[105]$. & “29. [Courante]" [D] & E-Mn, M1360, fol. $243 \mathrm{~V}$ \\
\hline [106.] & "Contradansa” [g] & $\begin{array}{l}\text { P-BRad, MS 964, fol. 227v; E-Mn, M815, fols. 9-11v ("faborita”); P[remier] } \\
\text { Recueil de danses de bal pour l"année } 1703 \text { (Paris, 1702), } 1 \text { ("l"Air de } \\
\text { la contre danse" / "Les contrefaiseurs"). See Russell," no. } 38 \text {. }\end{array}$ \\
\hline$[107]$. & "Alemanda" [D] & $\begin{array}{l}\text { P-BRad, MS 964, fols. } 227 \mathrm{~V}-228 \text {; E-Mn, M815, fol. } 47 \text { (“Alemanda") and fols. } \\
56 \mathrm{~V}-57 \text { (“Minuet. inconstante fortuna."); L'Allemande dance nouvelle } \\
\text { (Paris, 1702). See Russell," no. } 40 .\end{array}$ \\
\hline
\end{tabular}

La Barre, Harpsichord Music, 5 (no. 2c).

Woolley, "Catalogue of the 'French Dances"”.

* See Gustafson, Chambonnières, s.p. (no. 150).

$\S \quad$ Brookes, British Keyboard Music, 328-329 (no. 1763); Bailey, ed., Late Seventeenth-Century

English Keyboard Music, 29 (no. 26).

** Gustafson, "Four Decades After".

i† Budasz, "Five-Course Guitar", 98-99.

\$ An altered version of a minuet and double known from French sources; the original version of the minuet appears alone on fols. 220v-221. See Gustafson, "Seventeenth-Century Harpsichord Music", 315.

$\S$ Gustafson, French Harpsichord Music.

*** Russell, ed., Santiago de Murcia 's "Códice Saldívar No. 4".

The popularity of French-style dance music in Spain c. 1700 has been explained as a result of French influence under the Bourbon monarchy of Philip V. ${ }^{10}$ Similarly, it is thought that the arrival in Lisbon of Marie-Françoise-Élisabeth of Savoy (1646-1683), as spouse of Afonso VI of Portugal, led to French cultural influences there. ${ }^{11}$ Between 1668 and 1670 the French violinist Michel Farinel was active in Lisbon and presumably brought French music and performance practices with him. ${ }^{12}$ The dancing masters at the Portuguese court were Portuguese, and apparently no source has come to light describing the types of French dances performed there before the mid-eighteenth century. ${ }^{13}$ However, Portuguese musicians of the late seventeenth century were conversant with French-style dance idioms, to judge from English manuscripts dating from the 1660s containing a suite and several courantes attributed to the violinist and composer Miguel Ferreira, one of the musicians in the retinue of Catarina da Bragança, spouse of Charles II of England. ${ }^{14}$ The popularity

${ }^{10}$ Esses, Dance and Instrumental Diferencias, vol. 1, 242.

${ }^{11}$ Budasz, "Five-Course Guitar", 101; Braga and Braga, Duas rainhas, 139-150.

${ }^{12}$ Massip, "Itinéraires d'un musicien européen".

${ }^{13}$ Campos, "Tratados de dança", 126. A collection of anonymous dances partly consisting of arrangements of Italian madrigals mentioned in the catalogue of the lost music library of King John IV implies that a six-part dance ensemble existed in Portugal in the late sixteenth century. See Primeira Parte do Index, 404-405.

${ }^{14}$ Ashbee, Thompson and Wainwright, Viola da Gamba Society Index, 95-103. For Ferreira, see Leech, "Ferreira, Miguel"; and Leech, "Musicians in the Catholic Chapel”, 577. 
of the minuet in the Iberian peninsula after 1700 also parallels its importance as a social dance at the court of Louis XIV in the first two decades of the eighteenth century and points to its adoption at the courts of Lisbon and Madrid. ${ }^{15}$ A description of a masked ball to mark the first birthday of the Portuguese Infanta D. Maria in 1712 gives an idea of the importance of elaborate balls for marking special occasions, as regularly occurred at the French court. The writer names in detail the members of the nobility who were assembled, remarking that "all of those who danced came in dresses covered in diamonds". ${ }^{16}$

\section{Martin y Coll's Anthologies and the Circulation of Dances via Short Scores}

Another explanation for why most of the Portuguese and Spanish sources of French-style dance music date from around 1700 or later is that this period coincided with its wider availability in print. Lully's stage works had been published by Christophe Ballard in full score as early as 1679, but in later decades the quantity of available sources began to increase as short scores started to appear, a production mirrored by the short scores emanating from Parisian scriptoria. ${ }^{17}$ Usually giving only the outer voices of homophonic textures, short scores were cheaper to produce and were presumably more widely available. Their significance is illustrated by a treble-bass collection published in Spain as Canciones Francesas, de todos ayres, para todos los instrumentos (Madrid, [1701]), an expanded reprint of a Ballard publication of suites assembled by Philidor the elder, Suite de dances pour les violons et haut-bois (Paris, 1699)..$^{18}$ Likewise illustrating the importance of printed sources is Santiago de Murcia's 1714 collection, which drew on the annual Recueil de dances assembled by Raoul Auger Feuillet and Louis Pécour in the first two decades of the eighteenth century; several of its pieces have been arranged from Feuillet and Pécour's publications, and it may be that the other French-style dances it contains derive from lost or unidentified prints. ${ }^{19}$ On the other hand, the significance of the Ballard publications of Lully's stage works and the sources derived from them is illustrated by the Martin y Coll manuscripts. Almost all their Lully dances are from the later, published works rather than the earlier ballets. It is unlikely, however, that copying was undertaken directly from Ballard's full scores: there is strong evidence to suggest that short scores were used.

The Lully pieces in Martin y Coll's 1709 anthology (M1360) are mostly either treble-bass outlines (i.e., short scores) - from which idiomatic arrangements could have been performed extemporaneously - or fully notated keyboard arrangements in which the original bass has been adjusted to accommodate a newly composed inner part. They

${ }^{15}$ For the ascendancy of the minuet, see Harris-Warrick, "Ballroom Dancing".

16 "Todos os que dançarão ião cubertos de diamantes, em diferentes trajos". Cunha de Ataíde, Portugal, Lisboa e a Corte nos reinados de D. Pedro II e D. João V, 240.

${ }^{17}$ For recent discussion of Ballard, see Broude and Cyr, "Partition réduite and partition générale". For manuscripts, see Schmidt, "Berkeley MS 454".

${ }_{18}$ Masson, "Le recueil madrilène".

${ }^{19}$ Russell, "Santiago de Murcia", 46-51. 
generally follow the printed melody and bass-lines closely and in one instance a title (Ballard's "Entrée de Bretons et Bretonnes" is called "Entrada de Bretons"); similarly, the title "Obra de Pensie [i.e., Persée, LWV 60]" suggests that the music's origin in some cases was known. A close relationship to Ballard's full score or a parallel short score is further implied by a peculiarity in the copy of a Menuet from Armide (LWV 71/13). In Ballard's published version a first-time bar consisting of the cadence chord and the first bar of the piece facilitates the repetition of the first half. ${ }^{20}$ In M1360 these bars have been retained, but without any indication of their first-time-bar function, an omission that is likely to reflect confusion reading directly from the print or a source close to it. In some instances, Martin y Coll also had access to authentic inner parts. There are traces of Lully's second recorder part whenever it plays in the context of a trio in the arrangement in M1360 of the Passacaille from Armide (LWV 71/61). Similarly, among the group of six minuets in Martin y Coll's earlier 1706 anthology (M1357), the three that originated as trios (LWV 60/5, 61/3 and 65/63) incorporate Lully's inner parts. In all these cases, however, the authentic trio textures are likely to stem from a short score, since these scores customarily included obbligato second-treble parts. ${ }^{21}$

It is likely that the copies of treble-bass scores also served as the starting points for Martin y Coll or a colleague in making idiomatic keyboard arrangements. It is true that the textures in the arrangements are also typical, by and large, of the arrangements of Lully's music found in French keyboard sources of the same period, which, according to David Chung, are usually short scores that have been "recast in the flexible three-part format common to seventeenth-century harpsichord music" - potentially, they could have derived from a French keyboard source. ${ }^{22}$ Gustafson has also pointed out that a few popular French pieces originally written for harpsichord are included in M1360, an indication that Martin y Coll had access to a French harpsichord manuscript or a source derived from one. ${ }^{23}$ However, the musical style suggests that these arrangements stemmed from the copyist himself or his colleagues. The tendency to incorporate division-like passagework (glosas) in the right-hand part is especially likely to have stemmed from a Spanish composer, since it is also a prominent feature of the organ pieces that draw upon French-style dance music in the same sources (see below).

\section{P-BRad, MS 964: The Continuing Circulation of Dances via Single-Line Sources}

The copies of French-style dances in P-BRad, MS 964, have several features in common with those in the Martin y Coll manuscripts: there is a demonstrable connection with the Ballard scores of Lully's stage works; furthermore, most appear only as two-part outlines. However, the manner in which they have been preserved in this source also highlights some important differences that are likely to reflect how they were transmitted to the compiler.

\footnotetext{
${ }^{20}$ Lully, Armide, 49.

${ }^{21}$ Broude and Cyr, "Partition réduite and partition générale", 605.

22 Chung, introduction to Keyboard Arrangements, vII.

${ }^{23}$ Gustafson, French Harpsichord Music, vol. 1, 88.
} 
Unlike the Martin y Coll anthologies, P-BRad, MS 964 is a complex manuscript guardbook with many fascicles of different paper types and is not limited to keyboard music. It contains three distinct repertories: a large collection of open-score keyboard works in contrapuntal genres; a set of responsories and lamentations for solo voice and continuo; and a collection of miscellaneous airs in two-stave keyboard score, among which are the French-style dances. ${ }^{24}$ Despite the codicological complexity of the source, a single scribe appears to have been responsible for about $80 \%$ of the copying. I have proposed elsewhere that he was Pedro de Araújo, an important organist and composer active in and near Braga in the north of Portugal in the late seventeenth and early eighteenth centuries, arguing that most of the manuscript was assembled for his own use and that of students between c. 1695 and c. $1715 .{ }^{25}$ A "personal" function of the manuscript may help to explain the draft-like appearance of the copies of French-style dances, in which numerous on-the-page corrections have been made.

The airs were copied before the manuscript was bound in three places (fols. 216-222, fols. 224-230 and fols. 253-259). An analysis of the copyist's handwriting, the paper and the musical style shows they are divisible into two sub-repertories: one consisting of the French-style dances, the other containing the remaining airs. Throughout the guardbook the copyist's handwriting takes two forms that are reflected in his bass clefs: one with two vertical strokes written over the clef, and another where this feature of the clef is absent. ${ }^{26}$ The two clef styles appear to reflect the chronology of the copying. The second was used for notating the French-style dances on a pair of nested bifolios (fols. 218-221v), using paper found elsewhere for keyboard music in open score. ${ }^{27}$ The first, however, is associated with the remaining airs, written partly on paper (used for fols. 217, 222) also found in a legal document in the Portuguese national archive (the Torre do Tombo) dated $1711 .{ }^{28}$ Also distinguishing the remaining airs from those on fols. 218-221v is their mostly Portuguese or Italian origin; the only exceptions are a pair of widely copied dances published in Feuillet and Pécour's Recueil de dances and a popular march by the English composer Jeremiah Clarke (T.436), which also found its way into Dutch and Swedish sources in the early eighteenth century (see Table 1). ${ }^{29}$ While it is likely that the remaining airs were copied

${ }^{24}$ For the open-score keyboard music, see Doderer, Obras selectas para órgão; and (edited from a different source) Conceição, Livro de obras de órgão.

${ }^{25}$ Andrew Woolley, unpublished paper "The Seventeenth-Century Keyboard Player's Workshop: A Case Study From Northern Portugal”, 18th Biennial International Conference on Baroque Music, Musicology and Cultural Heritage Department, Pavia University, Cremona, 10-15 July, 2018.

${ }^{26}$ Andrew Woolley, unpublished paper "Paper Types in 17th- and 18th-Century Portuguese Music Manuscripts: Braga, Arquivo Distrital, MS 964”, Interdisciplinary Conference on Iberian Manuscripts, Faculty of Social Sciences and Humanities - NOVA FCSH, Lisbon, 19-21 October, 2017.

${ }^{27}$ The same paper is also used for fols. 72-73, 94-97, 104-119, 223-224.

${ }^{28} \mathrm{P}-\mathrm{L}$ ant, PT/ADLSB/NOT/CNLSB1B/001-001/173. The paper contains a three-circles-with-crucifix watermark featuring the initials "GB / B" in the central circle and "2" in the lower circle.

${ }^{29}$ See Doderer, Otto pezzi; Silbiger, "Imitations of the Colascione", 94-96; Budasz, "Five-Course Guitar", 98-99. Known elsewhere as "Prince Eugene's March", Clarke's piece is entitled "Marcha" in P-BRad, MS 964 (fol. 259). For sources, see Taylor, Thematic Catalogue; and Répertoire 
after 1711, the date of the bifolio pair therefore remains uncertain, although its inclusion of music from Acis et Galatée indicates that it must have been copied after 1686.

There are very few titles on fols. $218-221 \mathrm{v}$, a feature that, combined with the copyist's habit of beginning a new piece immediately after the preceding one without a break, causes problems for determining the exact number of pieces copied on these leaves. New pieces begin with a time signature, but some time signatures have been added in a confusing manner at the beginning of second strains, as occurs in the piece on fols. $220 \mathrm{v}-221$. There are also several fragments or seemingly complete pieces that conclude unsatisfactorily, some of them being copied twice, apparently in order to achieve a more satisfactory version at the second attempt. A fragment of a Rigaudon by Pierre Gautier of Marseille (?1642-1696) on fol. 220v consists only of the first strain and is followed by a fragment, apparently in A minor, that makes little musical sense. ${ }^{30}$ Another copy on fol. 221, this time with Gautier's original second strain included, is complete but it, too, ends in garbled form. Similar confusion is found in the two minuet-like pieces that immediately follow the second version of the Rigaudon, and in a copy of a Menuet from Le triomphe de l'amour (LWV 59/27) that is complete, but is followed on the same system, after two minim rests, by an error-ridden, textless copy of Purcell's song "If Love's a Sweet Passion". ${ }^{11}$

Another factor contributing to the draft-like appearance of the French-style dances in P-BRad, MS 964 is that, unlike Martin y Coll, the compiler appears not to have had access to bass parts. This is reflected most clearly in on-the-page corrections showing heavy revision to the bass, as occurs at the opening of the tripartite piece on fol. $219 \mathrm{v}$, consisting of a minuet, a canary and another triple-time section. The lack of access to bass parts also becomes apparent from the pieces known from printed sources: whereas the melodies appear to derive ultimately from the prints, the basses depart from them completely, as can be seen in the copy of an Entrée from Thésée (LWV 51/32) (see Music example 1). Most of the changes to the melody can be explained as notational simplifications or errors. The simplifications include changing the dotted rhythms (probably representing an approximation of notes inégales) to straight quavers and the removal of bars associated with repeats, including first- and second-time bars for a repeat of bars 1-6 and a written-out repetition of the final four bars. Errors occur in bar 4 - the third note is wrong, and the rhythm is misinterpreted for the final three notes - as well as in bars 5 and 8 , where mis-pitching by a step has occurred. The bass, however, differs entirely from Ballard's and was even composed to fit the wrong melody notes; in bar 8 there is a cadence on $\mathrm{G}$ instead of a cadence on A. Being mostly limited to crotchets and minims, the MS 964 bass is little more than a rough outline and could well have been composed directly into the manuscript; a misjudged progression in bar 10, where the $\mathrm{C}$ cadence chosen by the copyist has an odd effect, suggests that there was a lack of prior planning.

International des Sources Musicales (RISM), https:/opac.rism.info, where they can be located by performing an incipit search.

${ }^{30}$ I am grateful to Bruce Gustafson for drawing my attention to this concordance. For Gautier, see Frémiot, "Gautier, Pierre (ii)".

${ }^{31}$ The inclusion of Purcell's song probably reflects its dissemination in a French translation. See Lebedinski, "Travels of a Tune". 


\section{Music example 1}

“Entrée des combatans" from Lully’s Thésée (LWV 51/32), bb. 1-10: P-Brad, MS 964, fol. 219r (above); printed edition from 1688 (below).
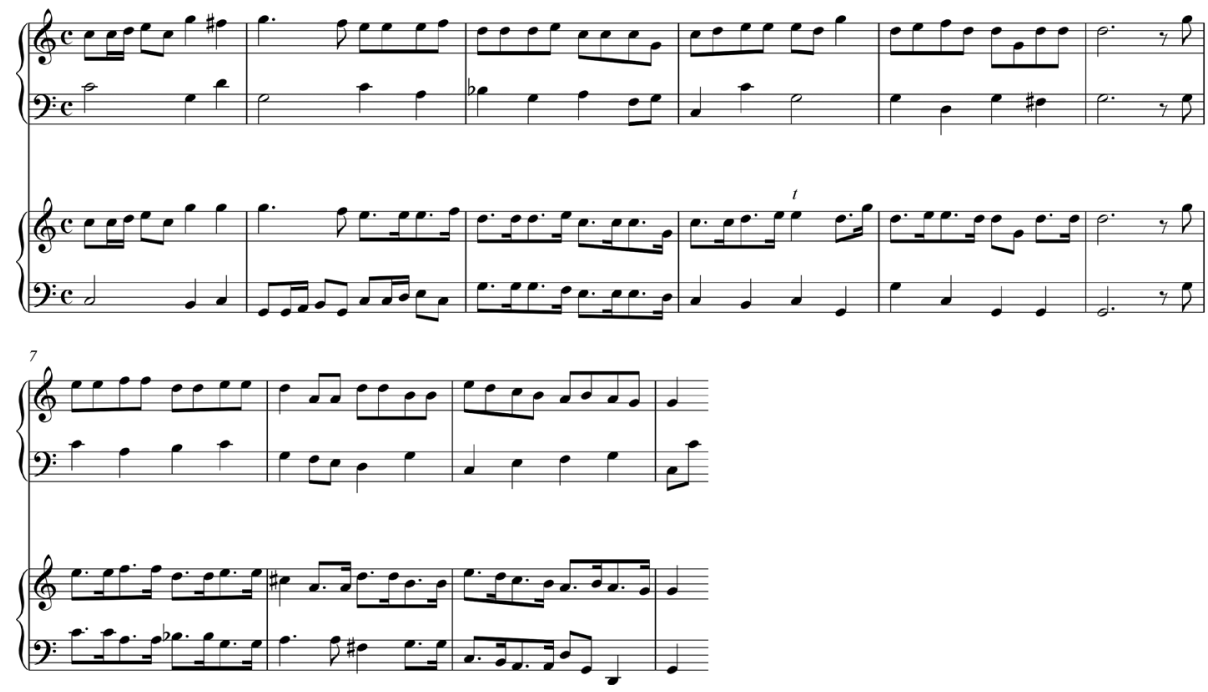

A potential explanation for why imperfections such as these were tolerated is that the copies were not intended to be definitive. Indeed, the copyist was evidently keen to work out several possibilities, as suggested by the duplicates. A Menuet from Persée (LWV 60/72) was copied twice, on fol. 218 and fol. 219v, but without its bass part the second time, perhaps because the intention, never acted upon, was to compose an improved version. Something similar is suggested by the three textless copies - one of which is a fragment giving just the first four bars - of the air "Vous ne devez plus attendre" from Amadis (LWV 63/36). The two completed copies give different but related bass parts, both differing substantially from the bass published by Ballard (see Music example 2). The fol. 221v version starts with a bass closer to that of Lully's original, which is probably a coincidence and simply a reflection of the attempt to improve on the version copied on fol. 219: its $\mathrm{i}-\mathrm{iv}-\mathrm{V}$ progression is clearly stronger. Otherwise, most differences between the two versions are minor: in bar 14 the harmony is modified to avoid static F-major harmony between bars 14-15 (and similarly in the parallel passage at bars 29-30); a suspension is added in bars 16-17; a harmonically stronger bass is supplied in bars 31-33. With recopying, the opportunity was also taken to correct editorially some of the melodic errors in the first copy. An accidental duplication of bar 9, not in Lully's original, has been deleted in the version on fol. 221v. Conversely, a bar that was omitted in the fol. 219 copy, bar 19, has been reinstated. 


\section{Music example 2}

"Vous ne devez plus attendre" from Lully's Amadis (LWV 63/36): printed edition from 1684 (treble and bass); P-BRad, MS 964, fol. 219 (bass); P-BRad, MS 964, fol. 221v (bass).

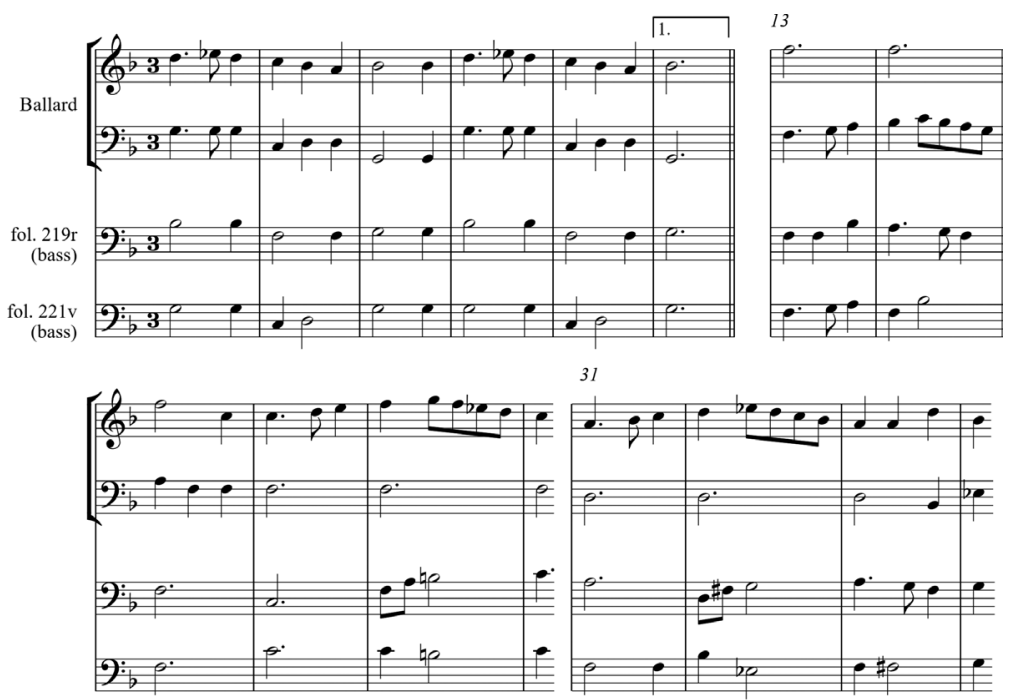

One of the few pieces for which a bass was clearly available is another by Pierre Gautier, published posthumously by Ballard as a duo entitled "Les heures heureuses" in Gautier's Symphonies [...] divisées par suites de tons (1707). However, although the print may have been the source in this case, Gautier's music is known to have circulated in Spain and Portugal independently of it. The Gautier Rigaudon in P-BRad, MS 964, discussed above, was clearly copied without access to the bass and is in the key of the version in F-Pn, Rés F 918, a manuscript collection of trios by Gautier, rather than the key of the version in the Symphonies, where it appears in D. ${ }^{32}$ The piece called "La Marche de Gantier" in E-Mn, M1360 (fol. 225), although not known from French sources, appears between two Lully pieces and has been connected by Gustafson to Pierre; in M1360 it is joined on the stave with a popular Rigaudon from Acis et Galatée (LWV 73/7), but is found as a single piece in another Spanish keyboard source, the Francisco de Tejada manuscript (E-Mn, M815, fol. 16v as "Marcha") as well as in GB-Ob, Mus. Sch. F.576 (fols. 76-75v), a manuscript of lute and keyboard music possibly of Dutch provenance. ${ }^{33} \mathrm{~A}$ second piece by Gautier in M1360 (fol. 209v), included in Rés F 918 but omitted in the Symphonies, also appears in the Tejada manuscript as "Minuet de la Marcha". ${ }^{34}$

${ }^{32}$ I am grateful to Bruce Gustafson for drawing my attention to these concordances.

${ }^{33}$ Gustafson, French Harpsichord Music, vol. 1, 88; Gustafson, "Four Decades After", 24. For E-Mn, M815, see Esses, Dance and Instrumental Diferencias, vol. 1, 272-273. For Mus. Sch. F.576, see Gustafson, French Harpsichord Music, vol. 1, 66; and Woolley, "English Keyboard Sources", 259-260.

${ }^{34}$ Gustafson, "Four Decades After", 24. 
Although there is some overlap in repertoire - the Gautier pieces, especially, suggest that Portuguese and Spanish musicians accessed French-style dance music from related sources - it is important to recognise that the P-BRad, MS 964 copyist worked from sources that were further removed from Ballard's prints than Martin y Coll's. His difficulty with producing coherent versions may in part have been due to his unfamiliarity with the idioms of French-style dance music; yet he was also a highly competent musician unlikely to have committed errors from mere sloppiness, which suggests that these problems were at least partly a reflection of the copy source. As such, they might have reached him via a single-line manuscript associated with a dancing master or violinist; in at least one surviving single-line source of French dance music probably associated with such an individual, rhythmic notation is approximated or absent and certain features such as titles, time signatures, key signatures and clear indications of where one piece ends and another begins are sometimes absent. ${ }^{35}$ The tripartite piece on fol. $219 \mathrm{v}$ also suggests that the repertoire was in part drawn from music intended specifically for dancing and therefore could have stemmed directly from a dancing master: multi-sectional structures of this kind where one section leads immediately onto another without a break are an identifying characteristic of late seventeenth-century and early eighteenth-century French ballroom music. ${ }^{36}$

\section{Adaptations of French Dance Music in Spain and Portugal}

The arrangements of French dance music considered so far were performable on several types of keyboard instrument or on a harp; others, however, have alterations specifically for organ. For organist-composers, such adaptations probably supplemented their day-to-day repertoire. Clerics in the early eighteenth century were moved to complain about the employment of idioms associated with minuets and contradances in liturgical organ music and were in general suspicious of dance music. ${ }^{37}$ In the 1730 s the Portuguese Padre Joseph de Souza of the Sé Catedral de Miranda do Douro declared that an organist "during the Mass and Divine Office must play sonorous, well-ordered music, without interruption from profane or lascivious harmonies [...] Among the profanities I intend to include Minuets and Contradances, which are not accessories to a serious work [...]." ${ }^{{ }^{38}}$ He objected that "Minuetes, etc." were replacing older types of music, likewise of secular origin but "less artificial [i.e., in a simpler style]" ("vierão substituir as vezes de sons antigos e profanos [...] por serem hüas composiçõens com mais artificio"). Moreover, because of the new fashion for dance styles in Bayles (music for festivities) and comedies ("os Bayles, e as comédias, e estam ja hoje tanto metidos a moda"), he warned of a danger that organists would be accused of playing badly if congregation members expecting to hear minuets

${ }^{35}$ Woolley, “Tunes of the Usual French Dances"”.

${ }^{36}$ Little and Marsh, La danse noble.

${ }^{37}$ Esses, Dance and Instrumental Diferencias, vol. 1, 524-525.

${ }^{38}$ The comments come from a manuscript document quoted in Gándara Eiroa, "Manuscrito M-471", 55-56. I am grateful to Zuelma Chaves for translation assistance. 
were left wanting (“"se entrão em hüa Cathedral, e não ouvem tocar Minuetes, logo dizem mal toca este Organista").

An indication that French-style dance music was performed in this context earlier in the century in Spain comes from Martin y Coll's 1706 collection (M1357). It includes two Lully arrangements with performance indications relevant to the organ: "Cancion de clarin, con eco a discrecion" (pp. 49-50) is an arrangement of a Menuet from Amadis (LWV 63/24) that includes crosses to show where echo effects could be incorporated on a double-manual instrument, and "Minue frances" (pp. 51-52) is an arrangement of a Rondeau from Persée (LWV 60/73), which also has crosses as well as fuerte markings, apparently in order to show where to change manuals. A French model can also be identified in a D-minor piece headed "discurso de mano derecha para corneta y ecos" (pp. 149-154), a title reflecting its multi-sectional structure and echo effects. It includes a section headed "cancion francesa" based on the Menuet LWV 54/11, a piece arranged elsewhere in the 1706 collection in the original key, G minor (pp. 274-275). The "cancion francesa" section is essentially a transposed version of the arrangement and includes the arrangement's melodic quaver motion not found in the Lully original. In the second half, however, it introduces an echo effect, notated as two four-bar phrases written twice. A notable feature of the "discurso de mano derecha" is that it is a multi-sectional organ piece adopting traditional techniques such as the representation, in triple time, of earlier duple-time material - in this case a toccata-like opening section, which is followed by a triple-time variation ${ }^{39}$ - yet several of the ideas are taken from dance music. The fugue-like section following the "cancion francesa", in duple time, has a subject recalling the theme of LWV 54/11, which begins by rising to the third degree of the scale and descending to the seventh degree. A triple-time section that follows has saraband characteristics.

The "discurso de mano derecha" may help to explain puzzling features of two further pieces with French associations: "Zarabanda francesa, despacio" (pp. 88-92) and another "Cancion françessa" (pp. 22-24), both of which are also multi-sectional organ pieces. The first section of the "Zarabanda francesa" recalls the similarly titled binary-form pieces in Sanz's Instrucción de música as well as a group of seven "Zarabandas" in M1360 (fols. 205v-208v), two of which, at least, are of French origin (see Table 1). The model, however, appears to be the piece entitled "Corriente; corneta" in M1357 (pp. 18-19), which opens with the same melodic figure featuring a descent of a fifth in the second bar, but in the minor mode. Unless the "Corriente; corneta" itself had a French model, the use of the word "francesa" may simply be a reference to the musical style rather than to the model's geographical origin. A giga-like movement in ${ }_{8}^{12}$, "Aire de chacona", then a variation based on the first section headed "cancion al mismo aire", follow the saraband opening; the piece concludes with fanfare-like figures. The "Cancion françessa", which seems to be in two movements (possibly three), also recalls the "discurso de mano derecha" in which, as mentioned above, a Lully minuet labelled "cancion francesa" has been incorporated; a French model may have existed likewise for the "Cancion françessa", although none

${ }^{39}$ A device used extensively by the major seventeenth-century Spanish organ composers, including Correa de Arauxo, Pablo Bruna and Joan Cabanilles. 
has yet been identified. Following a binary-form minuet, the second movement of this piece opens with a chaconne-like passage featuring a descending tetrachord in the bass.

In addition, there are several pieces modelled on French-style popular tunes: "Ruede la bola" (M1360, fols. 221-221v), a saraband that survives in English keyboard sources (see Table 1), and "Monica Forsata", a widely disseminated vocal bourée (LWV 14/2) also used as a model for French-style dance music in England. ${ }^{40}$ "Monica Forsata" went by several titles, as indicated by the Tejada manuscript, where it is called "el sarado, o Bella Lis [i.e., "Bel Iris"] por otro nombre" (M815, fol. 12v); two pieces based on it are included in M1357, both with divisions and echo effects (see Table 2). A surprising title for one of the versions in M1357, "tocata ytaliana $1^{\circ}$ tono mui despacio", suggests the involvement of two composers who contributed their own versions to Martin y Coll's collection, one of whom was unaware of the French origins of the piece. The version called "Cancion para la corneta con el eco" is copied again later in the manuscript with a different title ("Cancion real francesa") and is perhaps by Martin y Coll himself; it employs the device of a two-treble texture in the right-hand part, a texture suited to the divided register of a Spanish organ, with which it continues in the division section in duple quavers. The "tocata ytaliana", on the other hand, is a different piece that consists of an ornamented arrangement of the tune followed by a giga-like movement.

\section{Table 2}

LWV 14/2 in E-Mn, M1357

\begin{tabular}{|l|l|}
\hline Titles & Pages \\
\hline "Cancion para la corneta con el eco" / "Cancion real francesa" & $15-18 / 185-189$ \\
\hline "tocata ytaliana $1^{\circ}$ tono mui despacio" & $136-138$ \\
\hline
\end{tabular}

Titles such as "Ruede la bola" and "El sarado" imply the existence of another type of adaptation, namely the use of French-style dance models in vocal music. Joan Boronat Sanz has pointed out that "El sarado" refers to the tono humano "Al sarao, que el amor", a contrafactum adopting the LWV 14/2 tune..$^{41}$ Further pieces with vocal originals occur in a section of the Tejeda manuscript in treble-bass score (fols. $51 v-59 v$ ). ${ }^{42}$ Each piece in this section of the manuscript is headed "Minuet" (even though some are in duple time) and includes a textual incipit, implying the existence of a vocal version; furthermore, continuo figures and the word "Acomp. ${ }^{\text {to" }}$ above several of the basses suggests that these pieces once functioned as keyboard accompaniment parts, although no trace of an accompanying vocal partbook survives. The incipits are frequently limited to just two or three words, which makes positive identifications of the associated texts difficult. ${ }^{43}$ At least

${ }^{40}$ Esses, Dance and Instrumental Diferencias, vol. 1, 253, 263; and Woolley, "Catalogue of the 'French Dances"', no. 49. See also Woolley, "French Dances and the Consort Dances".

${ }^{41}$ Boronat Sanz, "Aspectos de la interpretación y estilo", 26. Modern edition: Josa and Lambea, Manojuelo poético-musical de Nueva York, 318-319 (no. 42).

${ }^{42}$ For the pieces in treble-bass score, see Esses, Dance and Instrumental Diferencias, vol. 1, 272.

${ }^{43}$ The text for "Minuet. No vengo ingrata ninfa" (fol. 56v; in fact a bourée) apparently survives; see Stein, Songs of Mortals, 388. "Minuet. La noche tenebrosa" (fol. 54v) is known from a different setting by Juan Hidalgo; see Stein, Songs of Mortals, 384. 
one of the potentially identified pieces, "Minuet. No vengo ingrata ninfa", has theatrical origins, however, a fact that may explain Joseph de Souza's claim that the inspiration for the use of dance styles in organ music came from the theatre (from bayles and comédias). In Portugal, allegorical bayles in Castilian were performed as part of the festivities for newly canonised saints; the texts of these were published in wordbooks implying that minuet style was adopted in the musical settings. The wordbook for festivities that took place in Braga in 1727, for example, contains five bayles divided into several movements or sections labelled "Introducçam", "Recitado", "A Duo", "Sonada", "Aria" and "Minuete". ${ }^{44}$

A musical source for Portuguese bayles dating from earlier in the eighteenth century that lacks anything recognisably derived from French-style dances has been edited by José Crisanto Gándara Eiroa. ${ }^{45}$ However, it is likely that minuet style was adopted in vocal music in Portugal before 1727: an earlier source of minuets, P-Lcg, MS without shelfmark, a manuscript probably dating from the first decade of the eighteenth century, appears to contain several with titles implying vocal origins. ${ }^{46}$ It is devoted mainly to tablatures for five-course guitar (viola) and bandora (bandurra), but also contains miscellaneous airs notated in a numerical cipher called "cifras aritmeticas" by the copyist (see Table 3 and Figure 2). This cipher, which is partially explained within an incomplete treatise at the rear of the manuscript, resembles the number tablature of Spanish keyboard sources and has been used to notate solo pieces for viola, bandora and harpsichord (cravo); the pieces for the last-named instrument use two simultaneous rows of numbers, one for each hand (the music for guitar and bandora uses a single row). ${ }^{47}$ An accurate transcription is prevented by the lack of rhythmic indications and time signatures - also a feature of the guitar and bandora tablatures of the manuscript - and by unexplained numbers with sharp signs that appear periodically above the row of numbers for the right hand. The titles implying vocal origins are "Augusto principe" (for viola), "Ananita galega" (for bandurra) and "3 Minuete $5^{\circ}$ tom Divina Filis" (for harpsichord)..$^{48}$ In any case, it is likely that some of the minuets were composed in Portugal. One of the harpsichord pieces (although not a minuet) is attributed to the early eighteenth-century Braga Cathedral organist Manuel de Mattos, also one of the composers for the bayles performed in Braga in 1727.49

${ }^{44}$ Gándara Eiroa, "Manuscrito M-471", 57-58. For the 1727 festivities in Braga, see Ferreira, Fastos Episcopaes da Igreja Primacial de Braga, III:453.

${ }^{45}$ Gándara Eiroa, "Manuscrito M-471", 485-889.

46 The watermark in the paper of fols. $39-48$ and $77-82$ of this manuscript is also found in a legal document in the Portuguese national archive dated 1707 (P-Lant, PT/ADLSB/NOT/ CNLSB1B/001-001/168). It is an Arms-of-Genoa mark with the initials "GD" and "P". The example in Lcg, MS without shelfmark is very similar in dimensions, being only $2 \mathrm{~mm}$ shorter.

${ }^{47}$ For Spanish number tablatures, see Apel, Notation of Polyphonic Music, 47-53.

${ }^{48}$ For concordances, see Budasz, "Five-Course Guitar", 98.

${ }^{49}$ For de Mattos, see Vieira, Diccionario biográphico, vol. 2, 59, 67; and Gándara Eiroa, "Manuscrito M-471", 89-90. 


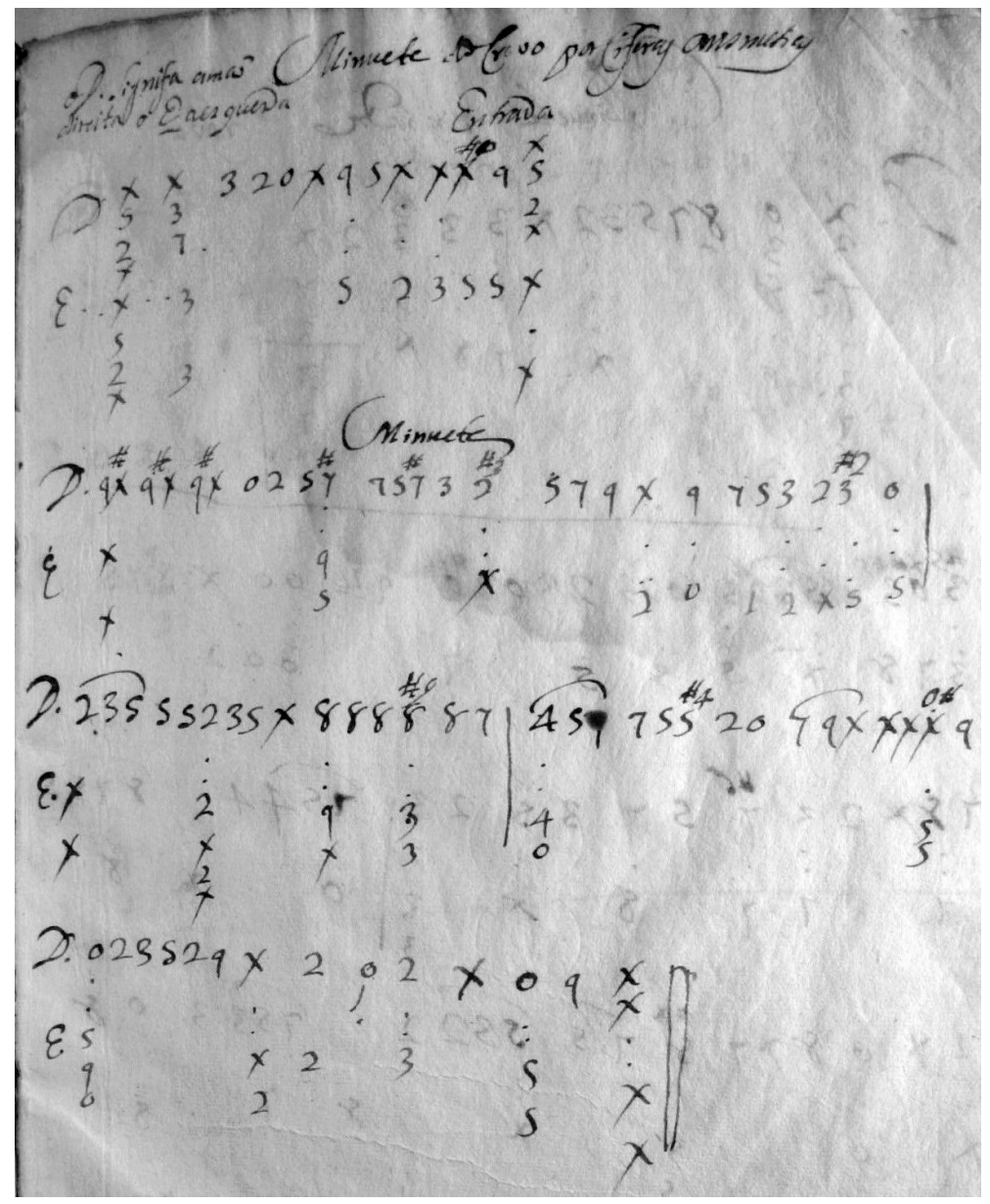

Figure 2

The beginning of the music for harpsichord in cifras aritmeticas in P-Lcg, MS without shelfmark. (Reproduced by permission of the Art Library of the Calouste Gulbenkian Foundation.)

\section{Table 3}

P-Lcg, MS without shelfmark: airs written in numerical cipher (cifras aritmeticas)

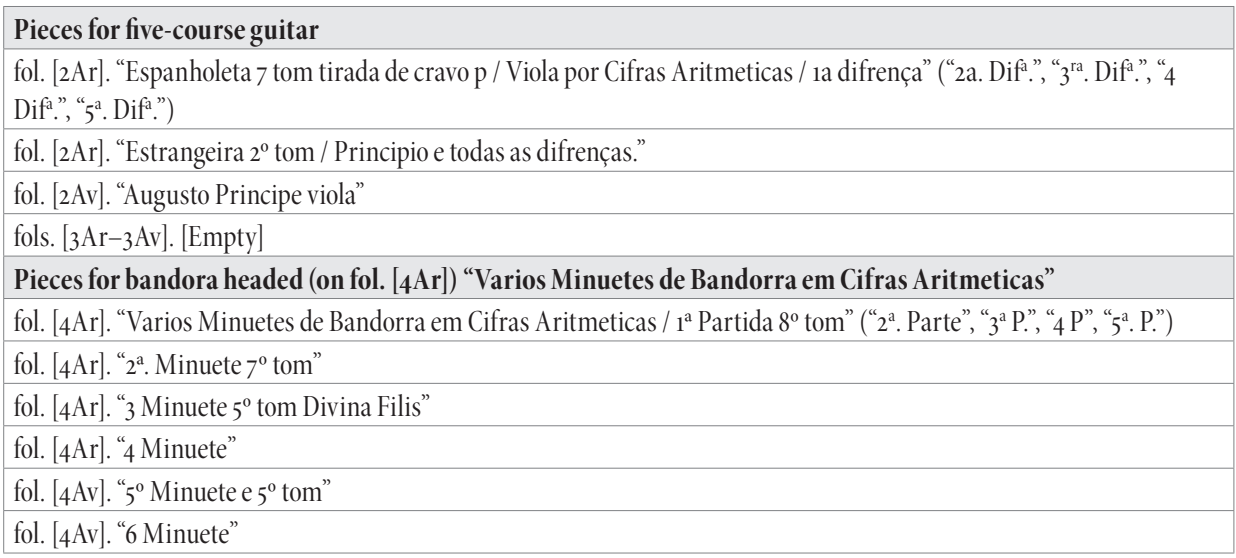




\begin{tabular}{|l|}
\hline Pieces for harpsichord headed (on fol. [5Ar] ) "Minuete do Cravo por Cifras Aritmeticas" \\
\hline fol. [5Ar]. "Entrada" \\
\hline fol. [5Ar]. "Minuete" \\
\hline fol. [5Av]. "Minuete Entrada Cravo" [Entrada] \\
\hline fol. [5Av]. [Minuete] \\
\hline fol. [6Ar]. "Ananita galega Cravo" \\
\hline fol. [6Av]. "Passo 5o tom Cravo" \\
\hline fol. [7Ar]. "Cravo", "Minuete / baixo", "Minuete 1 a p. te" $^{\text {to }}$ \\
\hline fol. [7Av]. "Minuete Cravo / Entrada" [Entrada] \\
\hline fol. [7Av]. [Minuete] \\
\hline fol. [8Ar]. "Contra dança Cravo" \\
\hline fol. [8Ar]. "Minuete d Cravo" \\
\hline fol. [8Av]. "Minuete d Cravo" \\
\hline fols. [8Av-9Ar]. "Giga alegro" \\
\hline fol. [9Av]. "Minuete Cravo" \\
\hline fol. [10Ar]. "Minuete d Cravo" \\
\hline fol. [10Av]. [Empty] \\
\hline fol. [11Ar]. "Consonancias do P. Mel de Mattos [Manuel de Mattos] Cravo" \\
\hline fol. [11Ar]. "Minuete" \\
\hline fol. [11Av]. "Minuete" \\
\hline fol. [12Ar]. Minuete de Cravo \\
\hline
\end{tabular}

\section{Conclusion}

The Portuguese and Spanish sources of French-style dance music underline the importance of French short scores for the dissemination of this music in the early eighteenth century. In northern Europe the popularity of Lully's music outside of France emerged slightly earlier, in the 1680s, when extracts from his operas started to be assembled in partbooks, often for amateur musicians, so that they could be performed as chamber music - a market aimed at, for instance, by the Amsterdam publisher Estienne Roger, whose Les trios des opera de Monsieur de Lully appeared 1691-1692. ${ }^{50}$ Its adoption in Portugal and Spain only later can probably be put down to a lack of suitable consorts and the fact that access to this music came only later via imported short scores. ${ }^{51}$ P-BRad, MS 964, however, implies a continuation of single-line dissemination of this music associated with its aural transmission via dancing masters or violinists associated with dance music.

Another point emerging from these sources concerns the role of local musicians in adapting this music to their own needs. Even the more straightforward arrangements show signs of creative involvement in the form of division-like insertions for the right-hand. However, it is likely that in performance - especially in the hands of organist-composers

${ }^{50}$ Holman, Four and Twenty Fiddlers, 313; Robertson, Courtly Consort Suite, 61-63.

${ }^{51}$ On the limited amateur market in Spain, see Esses, Dance and Instrumental Diferencias, vol. 1, 52-53. 
- adaptation typically went much further. The treble-bass outlines in the Martin y Coll manuscripts and P-BRad, MS 964 may have served the needs of organists, since such skeletons were potential templates for extemporisation. Some idea of their adaptation practices comes from E-Mn, M1357, which illustrates how the dances were modified in accordance with local performance practices and compositional techniques: we see the incorporation of extensive ornamentation or full-blown divisions as well as the framing of some of these dances within longer pieces in which traditional structural techniques are maintained. At present, there is only limited knowledge of the adoption of French-style dance music in other kinds of music. However, the keyboard sources imply that its idioms were incorporated widely into vocal music; further investigation might show how composers were influenced by them more generally in vocal genres such as the cantata humana.

\section{Appendix}

Thematic locator for pieces in Table 1 not known to be by Lully

The following thematic locator is modelled on the locator system developed by Bruce Gustafson. ${ }^{52}$ Each incipit gives the metre (" 2 " for duple time, " 3 " for triple time), followed by a colon, then the incipit itself in which the degrees of the scale are represented by numbers, ignoring their relative pitch and treating minor and major, and any chromatically altered scale degrees, as equivalent (e.g. the tonic is " 1 ", the supertonic is " 2 ", the major or minor third degree is " 3 ", and so on). The spaces between the numbers represent the bar-lines. All simple triple-time pieces notated in ${ }_{4}^{6}$ have incipits in ${ }_{4}^{3}$. Tonalities are indicated in the central column.

\begin{tabular}{|c|c|l|}
\hline & \multicolumn{3}{|l|}{ Sarabande } \\
\hline$[1]$. & {$[\mathrm{d}]$} & $3: 11712256565443$ \\
\hline$[2]$. & {$[\mathrm{D} / \mathrm{C}]$} & $3: 5123455154321$ \\
\hline$[3]$. & {$[\mathrm{D}]$} & $3: 12345123211123451232$ \\
\hline$[4]$. & {$[\mathrm{C}]$} & $3: 11712256434551$ \\
\hline$[5]$. & {$[\mathrm{d}]$} & $3: 33323127123232$ \\
\hline$[6]$. & {$[\mathrm{a}]$} & $3: 33321555437$ \\
\hline$[7]$. & {$[\mathrm{a}]$} & $3: 1231543454321$ \\
\hline$[8]$. & {$[\mathrm{C}]$} & $3: 1554345432121$ \\
\hline$[9]$. & {$[\mathrm{C}]$} & $3: 156334565432121$ \\
\hline$[10]$. & {$[\mathrm{C}]$} & $3: 345543671171$ \\
\hline$[11]$. & {$[\mathrm{C}]$} & $3: 155543453421$ \\
\hline$[12]$. & {$[\mathrm{C}]$} & $3: 3333144432$ \\
\hline$[13]$. & {$[\mathrm{D}]$} & $3: 554323423321$ \\
\hline$[14]$. & {$[\mathrm{d}]$} & $3: 555543221765$ \\
\hline$[15]$. & {$[\mathrm{C}]$} & $3: 55656711271$ \\
\hline$[17]$. & {$[\mathrm{a}]$} & $3: 1234555432145671$ \\
\hline
\end{tabular}

${ }^{52}$ See Gustafson, Chambonnières; and Gustafson with Leshinskie, Thematic Locator. 


\begin{tabular}{|c|c|c|}
\hline \multicolumn{3}{|r|}{ Menuet } \\
\hline [18.] & [d] & 3: 553676542534321 \\
\hline [21.] & [g] & $3: 171232342317121$ \\
\hline [22.] & {$[\mathrm{G}]$} & 3:34321565 671 765 \\
\hline [28.] & [d] & 3: 1511232234234321 \\
\hline [29.] & [a] & 3:1756454565 \\
\hline [30.] & {$[\mathrm{C}]$} & 3: 171234565436545 \\
\hline [31.] & {$[\mathrm{C}]$} & 3: 1671712342534321 \\
\hline [32.] & {$[\mathrm{C}]$} & 3:112323434564545465 \\
\hline [33.] & {$[\mathrm{C}]$} & 3:34321 221712123 \\
\hline [34.] & {$[\mathrm{C}]$} & 3:51234321232 \\
\hline [38.] & {$[\mathrm{D}]$} & 3: 5564453432121232 \\
\hline [39.] & [d] & $3: 331556454323$ \\
\hline [40.] & [B flat] & 3:55456654565 \\
\hline [41.] & [B flat] & 3:12343217 11712 \\
\hline [44.] & {$[\mathrm{C}]$} & 3: 5356545432323434 \\
\hline [45.] & [D] & 3: 5653421712345 \\
\hline [46.] & [D] & $3: 345234321232345$ \\
\hline [47.] & [g] & 3:1231271217123 \\
\hline [50.] & [D] & 3: 131432717121 \\
\hline [51.] & [D] & 3: 535134232343 \\
\hline [52.] & [a] & 3:55443322 \\
\hline [53.] & {$[\mathrm{G}]$} & 3: 1512123432121765 \\
\hline [54.] & {$[\mathrm{C}]$} & 3:1232 1276717 \\
\hline [55.] & {$[\mathrm{C}]$} & 3:321534321 21232 \\
\hline [57.] & {$[\mathrm{C}]$} & 3: 1711123456454565 \\
\hline [57.] & {$[\mathrm{C}]$} & 3: 1711123456454565 \\
\hline [58.] & {$[\mathrm{C}]$} & $\begin{array}{l}\text { 3: } 1123243432121232 ; \\
\text { 3: } 171234212345345434\end{array}$ \\
\hline [62.] & [d] & 3: 1231231432342 \\
\hline [64.] & {$[\mathrm{c}]$} & 3:5432177 1232343454 \\
\hline [65.] & [d] & 3:217 144323452 \\
\hline [66.] & {$[\mathrm{C}]$} & 3:3434565433452 \\
\hline [67.] & [d] & 3:13231271 21232 \\
\hline [68.] & {$[\mathrm{C}]$} & 3:56512142434321 \\
\hline [69.] & [D] & 3:123531564321232 \\
\hline [70.] & [d] & 3: 13513571255 \\
\hline [71.] & {$[\mathrm{D}]$} & 3: 1134556465434321 \\
\hline \multicolumn{3}{|c|}{ Canary / Passepied / Gigue } \\
\hline [72.] & {$[\mathrm{C}]$} & 3:32312345434556543 \\
\hline [74.] & {$[\mathrm{C}]$} & 3: 1231234321 \\
\hline [75.] & [d] & 3:132151217 1 \\
\hline [78.] & {$[\mathrm{c}]$} & 3:15512345321 \\
\hline [79.] & {$[\mathrm{C}]$} & 3: 1231555512 \\
\hline
\end{tabular}




\begin{tabular}{|c|c|c|}
\hline \multicolumn{3}{|c|}{ Chaconne / Passacaille } \\
\hline [81.] & [d] & 3:131212543 \\
\hline [82.] & {$[\mathrm{C}]$} & 3:12314234253453667567 \\
\hline \multicolumn{3}{|c|}{ Marche / Rigaudon / multi-sectional } \\
\hline [84.] & {$[g]$} & 3:55177 12322551 \\
\hline [85.] & {$[\mathrm{C}]$} & 3: 111151331553665115 \\
\hline [87.] & [B flat] & 2: 32153654321 \\
\hline [88.] & {$[g]$} & 2: 54321171234345 \\
\hline [89.] & [B flat] & 2: 1517167123212345 \\
\hline [92.] & {$[\mathrm{C}]$} & 2: 1234543234271232 \\
\hline \multicolumn{3}{|r|}{ Gavotte } \\
\hline [93.] & [d] & 2: 15315567171231 \\
\hline [94.] & [a] & 2: 12345564345 \\
\hline \multicolumn{3}{|r|}{ Bourée } \\
\hline [96.] & [d] & 2:32 111711123 \\
\hline [99.] & [g] & 2: 13154342253211755 \\
\hline [100.] & {$[\mathrm{F}]$} & 2: 51123222366671275 \\
\hline [101.] & {$[\mathrm{C}]$} & 2: 5123153432 \\
\hline [103.] & [d] & 2: 5323121232532345 \\
\hline \multicolumn{3}{|r|}{ Other } \\
\hline [105.] & [D] & 3:1 151315555553454 \\
\hline [106.] & [g] & 2: 34555564543253 \\
\hline [107.] & [D] & 2: 51535153123432317121 \\
\hline
\end{tabular}




\section{Sources and Bibliography}

MANusCRIPT SOURCES

Braga, Arquivo Distrital (P-BRad), MS 964.

E-Mn, M815, M1357, M1360.

GB-Ob, Mus. Sch. F.576.

P-Lant, PT/ADLSB/NOT/CNLSB1B/001-001/168.

P-Lcg, MS without shelfmark.

\section{PRINTEd SOURCES}

Lully, Jean-Baptiste. Amadis, Tragedie en musique. Paris: Christophe Ballard, 1684.

—. Armide, Tragédie mise en musique. Paris: Christophe Ballard, 1686.

. Thésée: Tragédie mise en musique. Paris: Christophe Ballard, 1688.

\section{MODERN EDITIONS}

Arbeau, Thoinot. Orchésographie. Translated by Mary Stewart Evans, reprinted with a new introduction by Julia Sutton. New York: Dover Publications, 1967.

Bailey, Candace, ed. Late Seventeenth-Century English Keyboard Music: Bodleian Library Ms. Mus. Sch. D.219, Oxford Christ Church, Mus. Ms. 1177. Recent Researches in the Music of the Baroque Era 81. Madison, WI: A-R Editions, 1997.

Chung, David. Introduction to Keyboard Arrangements of Music, by Jean-Baptiste Lully, I-XVIII. Edited by David Chung. Monuments of Seventeenth-Century Music 1. Web Library of Seventeenth-Century Music. New York: Society for Seventeenth-Century Music, 2014.

Conceição, Roque da. Livro de obras de órgão. 2nd ed. Edited by Klaus Speer. Portugaliae Musica 9. Lisbon: Calouste Gulbenkian Foundation, 1998.

Cunha de Ataíde, Tristão da. Portugal, Lisboa e a Corte nos reinados de D. Pedro II e D. João V: Memórias históricas. Edited with an introduction by António Vasconcelos de Saldanha, Carmen M. Radulet, Mafalda Enes Dias and Pedro Janarra. Lisbon: Chaves Ferreira, [1990].

Doderer, Gerhard, ed. Obras selectas para órgão: MS 964 da Biblioteca Pública de Braga. Portugaliae Musica 25. Lisbon: Fundação Calouste Gulbenkian, 1974.

- Otto pezzi per strumenti a tastiera: Di compositori della scuola di Bernardo Pasquini. Milan: Suvini Zerboni, 1973.

Josa, Lola, and Mariano Lambea, eds. Manojuelo poético-musical de Nueva York: The Hispanic Society of America. Cancioneros Musicales de Poetas del Siglo de Oro 5. Madrid: Consejo Superior de Investigaciones Científicas, 2008. http://libros.csic.es/ product info.php?products id=191.

La Barre. Harpsichord Music Associated with the Name La Barre. Edited by Bruce Gustafson and R. Peter Wolf. The Art of the Keyboard 4. New York: The Broude Trust, 1999.

Playford, John. The Complete Country Dance Tunes: From Playford's Dancing Master, 1651-c. 1728. Edited by Jeremy Barlow. London: Faber, 1985.

Primeira Parte do Index da Livraria de Música do Mvyto Alto, e Poderoso Rey Dom João o IV Nosso Senhor. Lisbon: 1649; Porto: 1874. 
Russell, Craig H., ed. Santiago de Murcia 's “Códice Saldivar No. 4”: A Treasury of Secular Guitar Music from Baroque Mexico. Urbana: University of Illinois Press, 1995.

\section{LITERATURE}

Apel, Willi. The Notation of Polyphonic Music, 900-1600. 5th ed. Cambridge, MA: The Medieaval Academy of America, 1953.

Ashbee, Andrew, Robert Thompson and Jonathan Wainwright. The Viola da Gamba Society Index of Manuscripts Containing Consort Music. Vol. 2. Aldershot: Ashgate, 2008.

Boronat Sanz, Joan. “Aspectos de la interpretación y estilo en la praxis del acompañamiento y el bajo continuo en el repertorio español de los siglos XVI a XVIII". Master's thesis, Fachhochschule Nordwestschweiz, 2013. https://doi.org/10.13140/2.1.1950.3360.

Brookes, Virginia. British Keyboard Music to c. 1660: Sources and Thematic Index. Oxford: Clarendon Press, 1996.

Brooks, Lynn Matluck. The Art of Dancing in Seventeenth-Century Spain: Juan de Esquivel Navarro and his World. Lewisburg: Bucknell University Press, 2003.

Broude, Ronald, and Mary Cyr. "Partition réduite and partition générale in the Age of Louis XIV: Reassessing the Relationship". Early Music 46, no. 4 (2018): 599-613. https://doi.org/10.1093/em/cay069.

Budasz, Rogério. "The Five-Course Guitar (viola) in Portugal and Brazil in the Late Seventeenth and Early Eighteenth Centuries". PhD diss., University of Southern California, Los Angeles, 2001.

Campos, Maria Alexandra Mendes Ribeiro Canaveira de. "Tratados de dança em Portugal no século XVIII: O lugar da dança na sociedade da época moderna”. Master's thesis, Universidade Nova de Lisboa, 2009.

Doderer, Gerhard. Orgelmusik und Orgelbau im Portugal des 17. Jahrhunderts: Untersuchungen an Hand des Ms. 964 der Biblioteca Pública in Braga. Tutzing: Schneider, 1978.

Drumond Braga, Isabel, and Paulo Drumond Braga. Duas rainhas em tempos de novos equilibrios europeus: Maria Francisca Isabel de Saboia, Maria Sofia Isabel de Neuburg. Lisbon: Círculo de Leitores, 2011.

Esses, Maurice. Dance and Instrumental Diferencias in Spain During the 17th and early 18th Centuries. 3 vols. Stuyvesant, NY: Pendragon, 1992-1994.

Ferreira, José Augusto. Fastos episcopaes da Igreja Primacial de Braga (sec. III-sec. XX). 4 vols. Braga: Mitra Bracarense, 1928-1935.

Frémiot, Marcel. “Gautier, Pierre (ii)”. In Grove Music Online. Accessed 19 December 2019. https://doi.org/10.1093/gmo/9781561592630.article.10759.

Gándara Eiroa, Xosé Crisanto. "Estudio y edición filológica y musical del manuscrito M-471 del Arquivo Distrital de Braga”. PhD diss., University of Coruña, 2009.

Gustafson, Bruce. Chambonnières: A Thematic Catalogue; The Complete Works of Jacques Champion de Chambonnières (1601/02-1672). JSCM Instrumenta 1. https://sscmjscm.org/instrumenta/instrumenta-volumes/instrumenta-volume-1/. - "Four Decades After French Harpsichord Music of the Seventeenth Century: Newly Discovered Sources". In Perspectives on Early Keyboard Music and Revival 
in the Twentieth Century, edited by Rachelle Taylor and Hank Knox, 7-45. Abingdon: Routledge, 2018. http://doi.org/10.4324/9781351254960-2.

. French Harpsichord Music of the 17th Century: A Thematic Catalog of the Sources with Commentary. 3 vols. Ann Arbor: UMI Research Press, 1979.

. "Seventeenth-Century Harpsichord Music from the House of Thurn und Taxis". In Fiori musicali: Liber amicorum Alexander Silbiger, edited by Claire Fontijn with Susan Parisi, 303-321. Detroit monographs in musicology 55. Sterling Heights: Harmonie Park Press, 2010.

Gustafson, Bruce, with Matthew Leshinskie. A Thematic Locator for the Works of JeanBaptiste Lully. Journal of Seventeenth-Century Music Instrumenta 4. New York: Society for Seventeenth-Century Music, 2017. https://sscm-jscm.org/instrumenta/ instrumenta-volumes/instrumenta-volume-4/.

Harris-Warrick, Rebecca. "Ballroom Dancing at the Court of Louis XIV". Early Music 14 (1986): 40-49. http://doi.org/10.1093/earlyj/14.1.41.

Holman, Peter. Four and Twenty Fiddlers: The Violin at the English Court 1540-1690. 2nd ed. Oxford: Clarendon Press, 1995.

—. "Terpsichore at 400: Michael Praetorius as a Collector of Dance Music". The Viola da Gamba Society Journal 6 (2012): 34-51.

Lebedinski, Ester. "The Travels of a Tune: Purcell's 'If love's a sweet passion' and the Cultural Translation of English Seventeenth-Century Music”. Early Music (forthcoming). Leech, Peter. "Ferreira, Miguel". Seventeenth-Century Music 11, no. 2 (2002). https:// sscm-sscm.org/17CM/vol\%2011\%20no\%202.pdf.

- "Musicians in the Catholic Chapel of Catherine of Braganza, 1662-92". Early Music 29, no. 4 (2001): 571-587. https://doi.org/10.1093/earlyj/XXIX.4.570.

Little, Meredith, and Carol G. Marsh. La danse noble: An Inventory of Dances and Sources. New York: Pendragon, 1992.

Massip, Catherine. "Itinéraires d'un musicien européen: L'autobiographie de Michel Farinel (1649-1726)". In Musik, Raum, Akkord, Bild: Festschrift zum 65. Geburtstag von Dorothea Baumann, edited by Antonio Baldassarre with Debra Pring, Lena Kopylova and Matthias von Orelli, 131-147. Bern: Peter Lang, 2011.

Masson, Paul-Marie. "Le recueil madrilène des 'Canciones Francesas [...] para todos los instrumentos' (1701)”. Acta Musicologica 10, no. 4 (1938): 174-189. https://doi. org/10.2307/931446.

Robertson, Michael. The Courtly Consort Suite in German-Speaking Europe, 1650-1706. Aldershot: Ashgate, 2009. https://doi.org/10.4324/9781315086873.

Russell, Craig H. "Santiago de Murcia: The French Connection in Baroque Spain". Journal of the Lute Society of America 15 (1982): 40-48.

Schmidt, Carl B. "Berkeley MS 454: Philidor L'Aîné's 'Enigma Variations"”. The Journal of Musicology 10, no. 3 (1992): 362-404. https://doi.org/10.1525/jm.1992.10.3.03a00040.

Schneider, Herbert. Chronologisch-thematisches Verzeichnis sämtlicher Werke von JeanBaptiste Lully. Tutzing: Hans Schneider, 1981.

Silbiger, Alexander. "Imitations of the Colascione in 17th-Century Keyboard Music". The Galpin Society Journal 33 (1980): 92-97. https://doi.org/10.2307/841830. 
Stein, Louise K. Songs of Mortals, Dialogues of the Gods: Music and Theatre in SeventeenthCentury Spain. Oxford: Clarendon, 1993.

Taylor, Thomas F. Thematic Catalogue of the Works of Jeremiah Clarke. Detroit: Information Coordinators, 1977.

Vera, Alejandro. “Santiago de Murcia’s Cifras selectas de guitarra (1722): A New Source for the Baroque Guitar”. Early Music 35, no. 2 (2007): 251-270. https://doi.org/10.1093/ em/cam013.

Vieira, Ernesto. Diccionario biográphico de músicos Portuguezes. 2 vols. Lisbon: Lambertini, 1900.

Ward, John M. "Newly Devis'd Measures for Jacobean Masques”. Acta Musicologica 60, no. 2 (1988): 111-142. https://doi.org/ 10.2307/932788.

Woolley, Andrew. “A Catalogue of the 'French Dances' in The Dancing Master and Apollo's Banquet (c. 1662-1687)". Revista Portuguesa de Musicologia (forthcoming). ."English Keyboard Sources and their Contexts, c. 1660-1720". PhD diss., University of Leeds, 2008.

_. "French Dances and the Consort Dances of Matthew Locke and his English Contemporaries". In Transitions in Mid-Baroque Music: Style, Genre and Performance, edited by Carrie Churnside. Woodbridge: Boydell and Brewer, forthcoming. . " "The Tunes of the Usual French Dances at COURT and DANCING SCHOOLS': The Repertoire and Musical Practice of Dancing Masters in Restoration England". In Musical Exchange between Britain and Europe, 1500-1800: Essays in Honour of Peter Holman, edited by John Cunningham and Bryan White. Woodbridge: Boydell and Brewer, forthcoming. 


\section{OD PRIREDB DO NOVIH SKLADB: FRANCOSKA PLESNA GLASBA 17. STOLETJA V PORTUGALSKIH IN S̆PANSKIH VIRIH}

\section{Povzetek}

Francosko plesno glasbo so v 17. stoletju širili predvsem plesni mojstri, kar je razvidno med drugim iz tiskane zbirke Terpsichore (1612) Michaela Praetoriusa. V njej je Praetorius objavil vrsto francoskih ali francosko navdahnjenih plesov v ansambelskih priredbah, katerih melodije si je izposodil pri Antoinu Emeraudu, francoskemu plesnemu mojstru, ki je deloval na dvoru Friedricha Ulricha, vojvode Braunsweiškega in Luneburškega, ki mu je bila Praetoriusova zbirka posvečena. V tistem času in predvsem tudi pozneje je sicer francoska plesna glasba krožila predvsem v priredbah za glasbila s tipkami, kitaro, lutnjo, harfo ali podobna glasbila, kar je pomemben znak, da so bili ti plesi namenjeni poklicnim glasbenikom za razne namene tudi izven plesišč.

Portugalski in španski viri plesne glasbe za glasbila s tipkami v francoskem stilu, ki datirajo v čas pred letom 1720, vsebujejo tako plese francoskega izvora kot tudi druge v enakem slogu, ki pa so vendarle drugačni in posebni; nekateri so izvirna dela portugalskih in španskih glasbenikov. Doslej so se raziskovalci osredotočali predvsem na španske vire in sta bila zato povsem spregledana dva rokopisa portugalskega izvora, ki vsebujeta plesno glasbo francoskega značaja: P-BRad, MS 964 in P-Lcg, MS (brez oznake).

Čeprav je bil francoski vpliv na kraljevem dvoru dejstvo, so pri širjenju tovrstne glasbe pomembno vlogo igrale predvsem francoske publikacije, ki so izhajale od devetdesetih let 17. stoletja dalje. To dokazujeta na primer dve rokopisni antologiji (E-Mn, M1357 in E-Mn, M1360) frančiškanskega brata, organista, skladatelja in teoretika Matina y Colla, saj vsebujeta priredbe glasbe Jeana-Baptista Lullyja, ki so bile neposredno pripravljene na podlagi izvlečkov iz orkestrskih partitur Lullyjevih scenskih del v izdajah Christopha Ballarda.

Po drugi strani pa v virih s plesi v francoskem slogu, kot je P-BRad, MS 964, manjka basovski part, kar nakazuje nadaljevanje prakse širjenja plesne glasbe v zapisih z eno samo melodično linijo. Plesi so v imenovanem rokopisu ohranjeni v obliki osnutka in $\mathrm{s}$ številnimi napakami, zaradi katerih je bila interpretacija nedvomno otežena. Po eni od možnih razlag za tako stanje bi lahko plese zbirke P-BRad, MS 964 prepisoval nevešči kopist neposredno iz izvirnika kakega plesnega mojstra, ki ni znal glasbe razumljivo notirati.

Ob tem da je bila plesna glasba zbrana v antologijah, je bila tudi na več značilnih načinov prilagojena potrebam lokalne uporabe. Številne orgelske skladbe v antologiji Martina y Colla (E-Mn, M1357) izhajajo neposredno iz Lullyjevih predlog in nam dajo slutiti, kako so tedanji organisti lahko te modele uporabljali za osnovo improvizacij. Organisti so skladali variacije in plese uporabljali kot gradivo za kompleksnejša glasbena dela, ki so odražala strukturo in oblikovne značilnosti španskega tienta.

Nadaljnji način prirejanja, ki se pojavlja tako v portugalskih kot tudi španskih virih, najdemo v posvetni vokalni glasbi ali njenih inštrumentalnih priredbah. Portugalski rokopis za petstrunsko kitaro, bandoro in čembalo (P-Lcg, MS), notiran s pomočjo aritmetičnih znakov, kaže na to, da so bile priredbe plesov francoskega značaja uporabljane za vokalno glasbo že v prvem desetletju 18. stoletja. 